\title{
Entrelacs
}

Cinéma et audiovisuel

Hors-série $n^{\circ} 4$ | 2016

Paysages en séries

\section{L'homme et la nature}

\section{Marie Maillos et Maylis Asté}

\section{OpenEdition}

Journals

Édition électronique

URL : http://journals.openedition.org/entrelacs/4391

DOI : 10.4000/entrelacs.4391

ISBN : $2261-5482$

ISSN : 2261-5482

Éditeur

Éditions Téraèdre

Édition imprimée

Date de publication : 1 novembre 2016

ISSN : 1266-7188

\section{Référence électronique}

Marie Maillos et Maylis Asté, «L'homme et la nature », Entrelacs [En ligne], Hors-série n 4 | 2016, mis en ligne le 06 février 2019, consulté le 24 septembre 2020. URL : http://journals.openedition.org/ entrelacs/4391 ; DOI : https://doi.org/10.4000/entrelacs.4391

Ce document a été généré automatiquement le 24 septembre 2020.

Tous droits réservés 


\title{
L'homme et la nature
}

\author{
Marie Maillos et Maylis Asté
}

\section{L'homme et la Nature}

1 La construction sociale de la notion de paysage a priori est indissociable de celle de nature : le sens commun fait de cette dernière la condition première du cadre paysager. La nature, ontologiquement et historiquement liée au paysage, participe ainsi de la dramaturgie de certaines séries télévisées. Au travers des éléments végétaux, elle interagit avec les personnages à l'intérieur du cadre sériel.

2 La mobilisation d'éléments naturels polarise des enjeux symboliques puissants au sein de la diégèse. Littérature, mythes et légendes font de la nature un espace multiréférentiel. La série joue de ces codes comme on le voit notamment au travers des nombreuses variations autour de la légende arthurienne.

3 Filmer au cœur des mondes ruraux, espaces souvent marginalisés et sous représentés, constitue l'une des singularités de séries telles que P'tit Quinquin ou True Detective. Ces œuvres mettent en scène l'affleurement de l'homme à son milieu. Comme le souligne Jean Mottet « aujourd'hui la recherche de nouveaux fondements à notre relation avec la nature (écologie, biodiversité...) entraîne des changements dans ses représentations artistiques et donne une singulière actualité à l'émergence des objets naturels ${ }^{1}{ }$. L'expression des paysages de nature dans la série participe ainsi qu'une quête symbolique, une quête du sens et d'essences.

\section{NOTES}

1. Mottet, Jean (dir.). L'herbe dans tous ses états. Paris : Champ Vallon, 2011. p. 7. 